UDC 94(470+571)“18”:327

Submitted: 02.09.2019

LBC 63.3(2)522-6

Accepted: 26.11.2019

\title{
MEANINGS OF THE RUSSIAN PRESENCE IN CENTRAL ASIA (ON THE EXAMPLE OF KULDJA) ${ }^{1}$
}

\author{
Svetlana A. Asanova \\ National Research Technological University “MISiS” Almalyk Branch, Almalyk, Republic of Uzbekistan
}

\begin{abstract}
Introduction. The issue of occupied Kuldja was one of the main points in the Russian-Chinese relations during the $70 \mathrm{~s}-80 \mathrm{~s}$ of the $19^{\text {th }}$ century. It originated in the mid-60s, when Kuldja came under the rule of the Taranchas. Being part of the Russian Empire from 1871 till 1881 Kuldja possessions had become a sore point in the relationship between Russia and China. The article discusses a range of problems that reveals Russia's desire to control this region. Methods and materials. The basis of the study was archive materials, publications of administrative persons, materials of authors who visited Kuldja and gave their conclusions, media reports. An attempt was made to reconstruct the view of Saint Petersburg, the Turkestan administration, officials at various levels, and society regarding the fate of Kuldja. Analysis. The author examines the fate of Kuldja in socio-political discourse in terms of its possible use for the empire. The possible control of Western China by the Muslim population on the basis of the interests of the empire, as well as border issues and getting clear natural boundaries with political and economic feasibilities are considered. Results. It is indicated that the conquest of Kuldja coincided with the mass migration of landless people from inner provinces of the Russian Empire into the region and the possibility of settling them down in the conquered territories which were economically deteriorating due to nonuse. This also leads to an attempt to solve the problem of unemployment by involving it in the cultivation of land, mining and development of trade. The study reflects what mechanisms were adopted to solve all the outlined tasks and what was obtained at the output.
\end{abstract}

Key words: Kuldja, Russian Empire, Ili region, Central Asia, natural borders, communication with China.

Citation. Asanova S.A. Meanings of the Russian Presence in Central Asia (On the Example of Kuldja). Vestnik Volgogradskogo gosudarstvennogo universiteta. Seriya 4. Istoriya. Regionovedenie. Mezhdunarodnye otnosheniya [Science Journal of Volgograd State University. History. Area Studies. International Relations], 2020, vol. 25, no. 5, pp. 64-76. (in Russian). DOI: https://doi.org/10.15688/jvolsu4.2020.5.6

УДК 94(470+571)“18”:327

Дата поступления статьи: 02.09.2019

ББК 63.3(2)522-6

Дата принятия статьи: 26.11.2019

\section{СМЫСЛЫ РОССИЙСКОГО ПРИСУТСТВИЯ В ЦЕНТРАЛЬНОЙ АЗИИ НА ПРИМЕРЕ КУЛЬДЖИ ${ }^{1}$}

\author{
Светлана Алексеевна Асанова \\ Алмалыкский филиал Национального исследовательского технологического университета «МИСиС», \\ г. Алмалык, Республика Узбекистан
}

\footnotetext{
Аннотация. Кульджинский вопрос занимал одно из основных мест в российско-китайских взаимоотношениях 70-80-х гг. ХІХ в., истоками уходя в середину 60-х гг. ХІХ в., когда Кульджа попала под власть таранчей. 을 Находясь в составе Российской империи в 1871-1881 гг., Кульджа ${ }^{2}$ была болевой точкой во взаимоотношени尺ิ ях между Россией и Китаем. В статье исследуется круг проблем, указывающих на стремление России контро¿ лировать данный регион. Автор рассматривает вопрос о судьбе Кульджи в общественно-политических спо$\circlearrowright$ рах с точки зрения предполагаемой ее пользы для империи. Судьба Кульджи анализируется с нескольких \%ิ сторон: как попытка контроля мусульманского населением Западного Китая исходя из интересов империи; как пограничная проблема и получение четких естественных границ; в целом с точки зрения политической и экономической целесообразности. Указывается, что завоевание Кульджи совпало со временем массового () притока в Туркестанский край безземельного населения из внутренних губерний Российской империи и
} 
возможного размещения его на территории Кульджи. Из этого вытекала и попытка решения проблемы занятости населения через привлечение его к обработке земли, добыче полезных ископаемых и развитию торговли. Какие механизмы принимались для решения всех намеченных задач и что было получено в итоге, отражено в результатах исследования.

Ключевые слова: Кульджа, Российская империя, Илийский край, Центральная Азия, естественные границы, отношения с Китаем.

Цитирование. Асанова С. А. Смыслы российского присутствия в Центральной Азии на примере Кульджи // Вестник Волгоградского государственного университета. Серия 4, История. Регионоведение. Международные отношения. - 2020. - Т. 25, № 5. - C. 64-76. - DOI: https://doi.org/10.15688/jvolsu4.2020.5.6

Введение. Кульджа, находясь в составе Туркестанского края Российской империи в 1871-1881 гг., обострила взаимоотношения между Россией и Китаем.

По вопросу занятия Кульджи в 1870 1871 гг. разгорелась полемика между Петербургом и туркестанской администрацией. Со стороны Петербурга этот шаг рассматривался как нежелательная мера [16], в то время как сторонником введения войск на территорию Кульджи был генерал-губернатор Туркестана К.П. Кауфман [17, с. 233]. Но на столичном совещании по вопросу о восстании в Западном Китае в апреле 1871 г. было всетаки решено занять Кульджу, но с тем, чтобы позже вернуть ее Китаю [15, с. 247].

Существует мнение, что оккупация Кульджи была вопросом времени, решение которого откладывалось, так как в Петербурге ожидали реакции маньчжурского правительства для определения совместных действий на данной территории. В начале 1871 г. было предложено начать сообща военные действия против таранчей и дунган, но на кульжинской границе произошло нападение на российские пограничные отряды, следствием стало покорение Кульджи. Одновременно со взятием Кульджи от китайского правительства был получен отказ в совместных действиях с русскими до тех пор, пока не будут усмирены волнения в Монголии. После этого последовало высочайшее повеление «установить спокойствие на границе, образовав, в случае возможности, из Кульджинского ханства особое владение под управлением кого-либо из туземцев и поставив его в вассальное к России отношение» [21, с. 103-104].

После завоевания Кульджи встал вопрос о возмещении убытков, нанесенных военными действиями, и установлении здесь российских административных порядков. Была раз- работана финансовая стратегия по возмещению убытков за счет контрибуции с населения покоренного края [9, л. 5-6; 48, л. 1-4] и обложение его дополнительными налогами [38, л. 7-8; 49, л. 10-12]. При этом генерал-губернатор К.П. Кауфман испрашивал разрешения расходовать доходы с Кульджи по своему усмотрению в качестве экстраординарного кредита [12, л. 1-2], на что получил одобрение в марте 1872 года [12, л. 4-5].

Одновременно с этими событиями в русском обществе стало набирать обороты мнение за сохранение Кульджи в составе Российской империи. В этом отношении нам интересны материалы, в которых прямо или косвенно задавался вопрос о том, как использовать данный регион, уже включенный в состав Туркестанского края, в контексте интересов Российской империи в Средней Азии.

Методы и материалы. В статье предпринята попытка реконструировать позиции Петербурга, туркестанской администрации, чиновников разных уровней (военных и гражданских), а также общества по отношению к судьбе Кульджи, уже включенной в состав Туркестанского генерал-губернаторства.

«Записка о современном положении нашем на границе с Западным Китаем» [21] капитана А. Шепелева ${ }^{3}$ явилась для нас отправным документом для определения интересов России в завоеванном крае. «Мнение посланника в Пекине действительного статского советника Е. Бюцова по Кульджинскому вопросу», в подготовленной В.И. Куликовым публикации [19], стало замыкающим звеном в вопросе использования Кульджи в интересах России, так как в 1878 г. уже встал вопрос об условиях ее возврата под власть Пекина [3].

Для восстановления дискуссионной линии между двумя этими документами были изучены материалы Центрального государ- 
ственного архива Республики Узбекистан (далее - ЦГА РУз) ${ }^{4}$, публикации административных лиц [26], а также материалы, авторы которых побывали в Кульдже и дали свои заключения [8;10;22; 27;31; 37; 40;43;46], а также сообщения средств массовой информации ${ }^{5}$. Газетные публикации явились для нас выразителем общественного мнения, так как мы не ставили задачу демонстрации исключительно официального взгляда на данный вопрос.

В современной российской историографии вопросы российско-китайских отношений, в том числе и в отношении Кульджи, заметно востребованы. Одним из основных специалистов по узловым вопросам русско-китайских взаимоотношений в Центральной Азии является В.А. Моисеев [28]. Характеристику российско-китайских отношений в хронологической и фактологической последовательности достаточно полно отразил И.М. Попов [42]. Причем в приводимых им аргументах прослеживается политическая их составляющая. Судьбу Синьцзяна в XIX в. рассматривает Д.В. Дубровская [18, с. 162-165]. Вопросы колонизации Кульджи в части пограничного и административного устройства с точки зрения «теории естественных границ»- С. Горшенина [11]. Д.В. Васильев [6, с. 348-360; 7] изучает организацию управления Илийским краем; Р.Ю. Почекаев [44; 45] - особенности правового положения Кульджи и ее населения; С.Н. Абашин [1] - устройство временного административного и народного управления в Кульдже; С.В. Моисеев - взаимоотношения России и уйгурского государства Йэттишар [29]; О.В. Боронин - проблему государства Йэттишар [4]. Причины и мотивы движения России на Восток рассматривает К.А. Сутеева [55]; А.В. Старцев - полемику в российских правительственных кругах по Илийскому вопросу [52]. Ранее фальсификацию «илийского вопроса» китайцами исследовал В.П. Гуревич [13]. Также написан ряд диссертационных работ, отражающих кульджинский вопрос с разных ракурсов российско-китайских взаимоотношений $[2 ; 52 ; 54 ; 56 ; 57 ; 59]$. Эти же вопросы затрагивали Н.Е. Бекмаханова [5, с. 14-45], В.Г. Дацышен [14, с. 5-51], В.И. Куликов [25].

Анализ. Изучив обширное количество источников по данному периоду, был выявлен относительный круг интересов Российской империи, которые могли быть обозначены как смыслы ее присутствия в Кульдже.

Контроль Кульджи - сфера национальных интересов. Завоевание Кульджи в 1871 г. совпало с периодом, когда она вышла из-под контроля Китая в результате восстания мусульман (1866-1867). Рассуждая о выгодности контроля Кульджи для России, большинство авторов ссылаются на аргументы о необходимости держать под контролем воинственное мусульманское население Синьцзяна (таранчей), которое составляло большинство населения Кульджи и вело активную мусульманскую пропаганду, привлекая в свои ряды новых последователей (дунган). Ими отмечалось, что практически все население Кульджи приняло ислам, сплотив, до того разъединенный народ, в единое целое [43, с. 31].

Считалось, что захватом Кульджи Россия гарантировала защиту интересов мусульманского населения. Если бы империя не взяла на себя эту миссию, то это сделал бы властитель Йэттишара, объединив под своею властью многочисленное единоверное население. Следствием этого могло стать создание нового мусульманского государства и возобновление волнений на российских окраинах [21, л. 118-119].

Еще одним доводом в пользу удержания Кульджи было то, что во времена контроля ее Китаем пограничные вопросы (выдача беглых и преступников) решались по требованию русских. После захвата власти таранчами эти споры оставались без действенного внимания кульджинского султана [24, л. 132].

Туркестанский генерал-губернатор К.П. Кауфман в целом был сторонником удержания Кульджи за Россией и поддержания власти Якуб-бека в Кашгаре, считая, что выгоднее иметь в соседстве с Туркестаном слабое мусульманское государство, чем Китай с неистощимыми материальными ресурсами [42]. Аналогичного мнения придерживался Е. Бюцов, считавший, что возвращение занятого силой оружия края прежнему владетелю будет расценено как признак слабости и как поражение России [19, с. 210]. Мнение Кауфмана о том, что возвращение Кульджи китайцам повлечет за собою новую резню, разделял и пред- 
ставитель министерства иностранных дел генерал-майор Богуславский [51, с. XLIV].

Встречалось также мнение, что китайцы, вступив в сношения с Европой и Америкой, с их помощью справились бы с мусульманами. Но при этом упускалось из виду, что последние, не имевшие в начале восстания ни оружия, ни армии, отняли у китайцев все это [34, с. 166-167]. Встречались и провокационные высказывания, приписываемые российским чиновникам, в частности Г.А. Колпаковскому: «То и другое племя (таранчи и дунгане. - C. A.) - заклятые враги китайцев, они открыто выражают надежду, что в ближайшем будущем Россия объявит войну Китаю и даст им случай отомстить ненавистному народу» [53, с. 269].

Таким образом, туркестанская администрация, демонстрируя внешнюю лояльность как к мусульманам Западного Китая, так и китайским властям, на деле пыталась удерживать регион ради возможных политических и экономических выгод.

Кульджа - удобная и перспективная граница для России. Еще одним доводом в полемике использования Кульджи Российской империей был пограничный вопрос. С присоединением Кульджи Россия получала твердые естественные границы в котловине междугорья (с севера - Алатау, с юга - Тянь-Шань), углом своим почти достигнув до всех военных и торговых путей Западного Китая.

Выгодность расположения Кульджинского края объяснялась, прежде всего, тем, что ограниченная со всех сторон горными хребтами с весьма немногими удобными перевалами через них она представляла чрезвычайно перспективную стратегическую позицию не только с точки зрения положения России относительно Китая, но и в связи с ее интересами в Средней Азии. Оставив за собой богатую и плодородную долину верхнего Или, Россия заменила бы совершенно открытую, пересекающую степь границу, естественным рубежом, оборона которого была бы возможна и незначительными силами [19, с. 209]. До занятия Кульджи российско-китайская граница представляла огромную равнину, контролировать которую, даже если она вся была бы заставлена войсками, было бы невозможно. Поэтому постоянно фиксировались пере- ходы ее кульджинскими киргизами и киргизами, находившимися в российском подданстве [35, с. 177$]$.

Плодородные почвы на благо империи. Кульджа была в числе выгодных и благодатных стран из-за сочетания плодородных почв с обильным орошением. И в случае необходимости могла накормить до 1 млн человек. До мусульманского восстания край кормил и обеспечивал занятостью более 300000 человек, о чем свидетельствовали некогда цветущие заброшенные города и деревни.

Илийская долина орошалась из реки Или и ее притоков, из которых были выведены огромные арыки. Вследствие развитой ирригации и теплого климата урожаи хлеба здесь были хорошими. Край был дешев из-за отсутствия в нем сбыта товара. Преимущественно выращивали пшеницу, рис, ячмень, лен, клевер, просо, хлопок низкого сорта, кунжут, табак. Садоводство существенно сократилось с приходом таранчей. До занятия ими края разница в цене за одни и те же товары между Кульджой и Верным доходила порой до 56 раз [33, с. 211].

Но плодородность почв, как выяснилось со временем, была относительной. Так, путешествовавший в 1878 г. по Кульдже С.Н. Алфераки ${ }^{6}$ отмечал, что засуха сменила обилие влаги, низкий уровень рек не позволял применять арычный способ орошения пашен. В сравнении с периодом завоевания растительность обеднела. Причина - отсутствие осадков [41].

Кульджа - место возможнного расселения безземельных крестьян. Считалось, что Кульджа по своим природным характеристикам может соперничать только с Ферганской долиной. Но при этом она выигрывает в меньшей плотности населения, что можно рассматривать как возможное место расселения безземельных крестьян из центральных губерний России.

Русская колония здесь развилась быстро, так как Кульджа по своему положению предоставляла выгодные условия для торговли с Западным Китаем, связывая его с рынками Ташкента и Коканда с одной стороны, а на севере - непосредственно с Семипалатинском и Омском [53, с. 248].

Еще одним шагом в сторону усиления русской колонизации края стала организация 
в Кульдже православной миссии. В 1877 г. на должность епископа Туркестанского и Ташкентского был назначен архимандрит Александр ${ }^{7}$, владевший китайским языком и знакомый с миссионерским делом. Он разработал проект организации миссионерского дела в Туркестане, который и начал реализовываться в Кульдже [47, с. 3-4].

Идея о возможном заселении края безземельными крестьянами имеет под собой достаточно веские основания, так как после завоевания Средней Азии и образования Туркестанского генерал-губернаторства туда направился внушительный поток безземельных крестьян, которыепервоначально обосновывались в Сырдарьинской области, позже в Ферганской долине и на побережье озера Иссык-Куль. Кульджа была вполне достойной альтернативой для решения вопроса с расселением именно из-за плодородности края и наличия большого количества пустующих деревень, жизнь в которых можно было оживить. Вероятно, этот фактор был не последним в плане использования Кульджи в интересах Туркестанского генерал-губернаторства.

Полезные ископаемые на благо Семиреченской области. Кульджа была богата полезными ископаемыми: каменным углем, медью, железом и др. Это обстоятельство можно было бы использовать на благо Семиреченской области. Так, начальник азиатского отдела Главного штаба А.Н. Куропаткин в письме военному министру Д.А. Милютину, ссылаясь на результаты геологических изысканий, подчеркивал, что с минеральными богатствами Кульджинской области не могут быть сравнимы богатства остальных частей Туркестана [19, с. 212].

И. Мушкетов, неоднократно путешествовавший по Средней Азии, специально изучал здесь залежи самых разнообразных полезных ископаемых, которые на сравнительно небольшом пространстве долины реки Или были сконцентрированы в огромном количестве. При этом он отмечал, что каменноугольные залежи Кульджи являются самыми мощными из всех известных залежей в Туркестане и каменноугольные образования занимают всю долину реки [30].

Но крупные залежи каменного угля в Кульдже, как показала практика, оказались не столь рентабельны, как ожидалось вначале. И хотя по сведениям исследователей приблизительный объем ежегодной добычи каменного угля составлял 600 000-800 000 пудов, их экономическая выгода была не столь существенной. Экономическая привлекательность этого сырья становилась очевидной только при увеличении его стоимости. Так, горный инженер Давыдов, командированный для исследования горнозаводского производства Кульджи, определил экономическую себестоимость получаемой прибыли отдельных промышленников, которая составляла 9,5 \% на первоначально затраченный капитал. Доходы в товарищеских артелях, занимавшихся добычей угля, были оценены им еще ниже. Причина низкая продажная стоимость на каменный уголь на месте добычи [32].

С проникновением российского капитала в каменноугольную промышленность появилась проблема иного характера. Как только цена на уголь выросла, началась массовая вырубка лесов вокруг Кульджи, причем как русскими войсками, так и населением. Причиной тому стало именно увеличение цены на уголь. Тогда кульджинская администрация забила тревогу о сохранении лесных массивов, увеличив штрафы за вырубку деревьев [39].

Регион, способный оживить торговлю c Китаем. Вопрос об оживлении торговли с Китаем начал обсуждаться задолго до включения Кульджи в состав Туркестанского генерал-губернаторства. Основным аргументом стал Кульджинский договор 1851 г., который, по мнению ряда авторов, заложил основы для устойчивой и постоянной торговли между двумя странами в Центральной Азии. При этом очевидно, что в момент его подписания Россия не стремилась к завоеванию Синьцзяна и использовала торговлю в качестве средства стабилизации отношений [50, с. 267 ; 58 , с. 310$]$.

После завоевания Кульджи вопрос об активизации торговли зазвучал с новой силой. В качестве подтверждения мнения многих авторов по этому вопросу достаточно привести точку зрения капитана А. Шепелева: «Наконец, торговля наша, которая после продолжительного застоя, могла надеяться подчинить своему преобладанию как Илийский бассейн, так и дунганские местности, а через них глубже проникнуть и в восточный 
Туркестан, должна будет отказаться от этих выгод с водворением китайцев в Кульджинском крае» [21, л. 120].

С другой стороны, с занятием Кульджи Россией прекратилась чайная торговля Китая со Средней Азией, а также торговля российскими товарами с Китаем через Урумчи. Со временем эту торговлю надеялись восстановить и вступить в конкуренцию с английскими товарами, которые могли проникать в Синьцзян только через Китай [34, с. 167-169].

В то же время считалось, что дунганское восстание оказало русской торговле важную услугу в плане возможного расширения торговли с Монголией. Так как китайские товары проникали в Монголию северным путем, а с падением Улясутая ${ }^{8}$ путь этот оказался закрыт, то Россия могла бы воспользоваться этой ситуацией и присовокупить в своих интересах и этот обширный торговый рынок [20, л. 256].

Но, как показала практика, многие надежды, связанные с торговлей, рушились изза низкой платежеспособности населения Кульджи и погодных условий. Так, со временем выяснилось, что Иртыш иногда мелеет уже в августе, пароходы доходят лишь до Павлодара, соответственно резко возрастает и цена за провоз товара. Соотношение между ввозом и вывозом тоже представлялось далеко не в пользу России. Как отмечал чиновник особых поручений при военном губернаторе Семиреченской области Н.Н. Пантусов, собиравший статистические сведения по Кульдже, вывоз зачастую превышал ввоз [36, c. 168-195]. Но при этом надо принять во внимание, что часть сырья не оставалась в России и сбывалась на ярмарках для вывоза в Западную Европу. Половину экспорта по стоимости составлял скот, вывозимый в Россию и Туркестанский край [23, л. 24-25].

К 1879 г. вопрос о выгодности западнокитайской территории в торговом плане и вовсе стал сомнительным - Китай закрыл торговлю для купцов российского происхождения, а также для лиц, путешествовавших с научными целями [42]. В целом имеющийся фактологический материал показывает, что торговле придавали второстепенное значение по сравнению с плодородием края.

Результаты. Таким образом, завоевав Кульджу, Петербург не имел четкого представ- ления, как можно ее использовать для империи. Именно это стало причиной возникшей общественно-политической дискуссии. У туркестанской администрации было более четкое представление на этот счет. Она планировала решить ряд проблем, которые можно сформулировать как смыслы российского присутствия в Кульдже.

Во-первых, контроль мусульманского населения Западного Китая, во главе с Якуббеком, позволял бы следить за политической обстановкой в Ферганской долине с самой высокой плотностью мусульманского населения в регионе. Это достигнуто не было.

Во-вторых, решив пограничную проблему и получив четкие естественные границы, можно было автоматически снять вопрос о кочевьях киргиз из Семиреченской области в Илийский край и обратно. Его неразрешенность создавала дополнительные неудобства дипломатическим чиновникам, которым приходилось решать вопросы незаконного пересечения границы людьми и скотом, пограничных грабежей. Кроме того, охрана горных участков границы представлялась экономически менее затратной.

В-третьих, судя по многочисленным описаниям края, туркестанская администрация не упускала из виду возможность расселения прибывающего безземельного крестьянства на завоеванной территории.

В-четвертых, решением проблемы расселения крестьян надеялись одновременно закрыть и проблему с их занятостью. Прогнозы были весьма оптимистичны, но реализовать их не успели из-за передачи края Китаю.

В-пятых, Кульджа была богата полезными ископаемыми, но горное производство с технической и экономической стороны было слабо развито. Единственный путь извлечения пользы из минерального богатства края виделся во введении рациональных приемов разработки, чего так же реализовать не удалось.

В-шестых, в Кульдже полностью отсутствовала какая-либо промышленность, кроме необходимых ремесел: кузнечного, шорного, горшечного, плотничьего и т. д. Этот регион нуждался во ввозе промышленных товаров, особенно тканей и металлических изделий. Но, несмотря на это, внешняя торговля края оказалась ничтожна из-за бедности населения. 
Препятствием для вывоза являлись случавшиеся природные катаклизмы. Поэтому предполагаемая ставка на оживление торговли в период нахождения Кульджи в составе Туркестанского генерал-губернаторства на тот момент оказалась несостоятельной.

В целом, если бы регион не был возращен Китаю, то часть оптимистичных прогнозов по использованию края могла быть воплощена в жизнь. На то имелись вполне реальные возможности.

\section{ПРИМЕЧАНИЯ}

${ }^{1}$ Исследование выполнено за счет гранта Российского научного фонда (проект № 19-18-00162), реализуемого в Институте языков и культур имени Льва Толстого.

The study was supported by the grant of the Russian Science Foundation (project No. 19-18-00162) implemented at the Leo Tolstoy Institute of Languages and Cultures.

${ }^{2}$ Кульджа - в данном контексте упоминается Кульджинский район в составе Туркестанского края Российской империи в период 1871-1882 годов.

${ }^{3}$ Капитан (в последующем генерал-майор) Александр Александрович Шепелев был руководителем экспедиции (осень 1871 г.), осуществившей топографирование Музаратского перевала и сделавшей вывод о возможности его военного использования, являющегося вместе с тем единственным удобным путем, связывающим Кульджинский край с Китаем.

${ }^{4}$ Фонд И-1 - «Канцелярия Туркестанского генерал-губернатора»; Фонд И-2 - «Дипломатический чиновник при Туркестанском генерал-губернаторе»; Фонд И-715 - «Туркестанский край. Сборник материалов для истории его завоевания».

${ }^{5}$ «Туркестанский сборник сочинений и статей, относящихся до Средней Азии вообще и Туркестанскому краю в особенности» (далее - ТС) состоит из 594 томов, хранящихся в Государственной Библиотеке Узбекистана имени Алишера Навои.

${ }^{6}$ Сергей Николаевич Алфераки - русский орнитолог и энтомолог. В 1879 г. путешествовал в Среднюю Азию, Казахстан и Западный Китай, в некоторых частях Тянь-Шаня он стал первым визитером из Европы.

${ }^{7}$ Преосв. Александр, в миру Андрей Кульчицкий, сын священника Гродненской губернии, родился в 1826 г.; в 1847 г. закончил курс в Литовской духовной семинарии и рукоположен в священника в г. Кобрин; овдовев, принял монашество и поступил в Санкт-Петербургскую Духовную Академию, в 1857 г. окончил курс со степенью кандидата.
8 Улиастай (с XIX в. и по 1989 г. по-русски именовался Улясутай, иногда на картах городу давалось наименование Джавхлантили, Джибхаланту) - город в Монголии, столица Дзабханского аймака, находящийся на северо-западе Монголии.

\section{СПИСОК ЛИТЕРАТУРЫ}

1. Абашин, С. Кульджинский вопрос / С. Абашин // Туркестан в имперской политике России : монография в документах. - М. : Кучково поле, 2016. - C. 120-132.

2. Ануфриев, К. С. Политика России и Китая в Центральной Азии: опыт сравнительно-исторического анализа : дис. ... канд. ист. наук / Ануфриев Кирилл Сергеевич. - Томск, 2010. - 282 с.

3. Асанова, С. А. Отдавать или не отдавать Кульджу? Общественно-политический дискурс 70-80-х гг. XIX в. / С. А. Асанова // Центральная Азия на перекрестке европейских и азиатских политических интересов: XVIII-XIX вв. : сб. науч. тр. Междунар. семинара, г. Алма-Ата, 19-23 августа 2019 г. / науч. ред. Д. В. Васильев. - М. : ОнтоПринт, 2019. - С. 274-282.

4. Боронин, О. В. Проблема государства Йэттишар и «Илийский кризис» / О. В. Боронин // Центральная Азия в составе Российской империи / отв. ред. С. Н. Абашин, Д. Ю. Арапов, Н. Е. Бекмаханова. М. : Новое литературное обозрение, 2008. - С. 78-81.

5. Бекмаханова, Н. Е. Присоединение Центральной Азии к Российской империи в XVIIIXIX вв. Историко-географическое исследование / Н. Е. Бекмаханова. - М. ; СПб. : Ин-т российской истории РАН : Центр гуманитарных инициатив, 2015. $-240 \mathrm{c}$.

6. Васильев, Д. В. Бремя империи. Административная политика России в Центральной Азии. Вторая половина ХІХ в. / Д. В. Васильев. - М. : Полит. энцикл., 2018. -638 с.

7. Васильев, Д. В. Китайский вопрос в Русском Туркестане: к истории российской администрации в Илийском крае / Д. В. Васильев // Вестник Томского государственного университета. - 2019. - № 449 (декабрь). - С. 93-101.

8. Вилькинс, А. Долина реки Или / А. Вилькинс // Русский вестник. - 1876. - № 8. - С. 483-509.

9. Воззвание к кульджинскому населению // Центральный государственный архив Республики Узбекистан (далее-ЦГА РУЗ). - Ф. И-1. -Оп. 27. Д. 742. - Л. 5-6 об.

10. Гинс, Г. Таранчи и Дунгане : (Очерки из поездки по Семиречью) / Г. Гинс // Исторический вестник. - 1911. - № 8. - С. 673-709.

11. Горшенина, С. Теория «естественных границ» и завоевание Кульджи (1870-1871 гг.): автопортрет российских военно-дипломатических элит 
Санкт-Петербурга и Туркестана / С. Горшенина // Ab Imperio. - 2014. - № 2. - C. 102-165.

12. Господину военному министру Туркестанский генерал-губернатор «Об испрошении Высочайшего повеления на оставление доходов по Кульджинской провинции» № 5374 от 11.12.1871 г. // ЦГА РУз. - Ф. И-1. - Оп. 27. - Д. 743. - Л. 1-5.

13. Гуревич, В. П. История «илийского вопроса» и ее китайские фальсификаторы / В. П. Гуревич // Документы опровергают. Против фальсификации истории русско-китайских отношений. - М. : Мысль, 1982. - С. 423-459.

14. Дацышен, В. Г. История российско-китайских отношений в конце XIX - начале XX в. / В. Г. Дацышен. - М. : Директ-Медиа, 2014. - 593 с.

15. Директор Азиатского департамента Начальнику главного штаба, 16 февраля 1872 года, № 604 // ЦГА РУ . - Ф. И-715. - Оп. 1. - Д. 49. - Л. 246-248.

16. Директор МИДа Военному министру, 7 октября 1870 года, № 2969 (секретно) // ЦГА РУз. Ф. И-715. - Оп. 1. - Д. 44. - Л. 225.

17. Директор МИДа Начальнику главного штаба, 9 октября 1870 года, № 3006 (доверительно) // ЦГА РУ . - Ф. И-715. - Оп. 1. - Д. 44. - Л. 233-240.

18. Дубровская, Д. В. Судьба Синьцзяна. Обретение Китаем «Новой границы» в конце XIX в. / Д. В. Дубровская. - М. : Ин-т востоковедения РАН, 1998. $-202 \mathrm{c}$.

19. «Если домогательства наши будут удовлетворены, отдача Кульджи не будет бесплодной жертвой». Записка посланника России в Китае Е.К. Бюцова. 1878 г. / подгот. В. И. Куликов // Исторический архив. - 1999. - № 4. - С. 206-212. - Электрон. текстовые дан. - Режим доступа: http://www.vostlit.info/ Texts/Dokumenty/China/XIX/1860-1880/Buezow_E_ K/zapiska_kuldza_1878.htm (дата обращения: 11.05.2019). - Загл. с экрана.

20. Записка генерал-майора Полторацкого о значении мусульманского восстания в Западном Китае. 7 марта 1870 г. // ЦГА РУз. - Ф. И-715. Оп. 1. - Д. 45. - Л. 241-260.

21. Записка о современном положении нашем на границе с Западным Китаем, капитана Шепелева. 27 января 1872 г. // ЦГА РУз. - Ф. И-715. - Оп. 1. Д. 49. - Л. 101-123.

22. Кадников, В. С. Из истории Кульджинского вопроса / В. С. Кадников // Исторический вестник, 1911. - № 124. - C. 893-909.

23. Копия с донесения Российского императорского Генерального консула в Кульдже Вице-директору первого департамента Министерства иностранных дел от 4 февраля 1910 г. за № 192 // ЦГА РУз. - Ф. И-2. - Оп. 1. - Д. 261. - Л. 21-47 об.

24. Командующий войсками Туркестанского округа Командующему войсками Семиреченской области. 23 сентября 1870 г. № 61. Ташкент. Копия с копии (секретно) // ЦГА РУз. - Ф. И-715. - Оп. 1. Д. 44. - Л. 132-133.

25. Куликов, В. И. Военное министерство и политика России в Кульджинском вопросе / В. И. Куликов // Войны в России. Сравнительный анализ : материалы 47-й Всерос. заоч. конф. / под ред. С. Н. Полторока. - СПб. : Нестор, 2007. - С. 49-54.

26. Куропаткин, А. Н. Русско-китайский вопpoc / А. Н. Куропаткин. - СПб., 1913. - 224 с.

27. Лэндсдель, Г. Поездка в Малый Тибет / Г. Лэндсдель // Русское обозрение. - 1891. - № 12. C. $700-732$.

28. Моисеев, В. А. Россия и Китай в Центральной Азии (вторая половина XIX - 1917 г.) / В. А. Моисеев. - Барнаул : Азбука, 2003. - 346 с.

29. Моисеев, С. В. Взаимоотношения России и уйгурского государства Йэттишар (1864-1877 гг.) / С. В. Моисеев. - Барнаул : Азбука, 2006. - 200 с.

30. Мушкетов, И. К вопросу о Кульдже / И. Мушкетов // Туркестанский сборник сочинений и статей, относящихся до Средней Азии вообще и Туркестанскому краю в особенности (далее TC). - T. 245. -C. 7-14.

31. «Мы в настоящее время стоим на крайне опасном пути». Записки русского дипломата барона Ф. Р. Остен-Сакена / подгот. В. Бухерт // Источник. Документы русской истории. - 2002. № 1 (55). - С. 13-15.

32. О горнозаводской промышленности Кульджинского ханства // ТС. - Т. 60. - С. 226-231.

33. О Кульдже // ТС. - Т. 60. - С. 202-221.

34. О настоящем положении мусульманской инсуррекции в Китае // ТС. - Т. 60. - С. 158-169.

35. Отношения наши к дунганам, Кашгару и Кульдже // ТС. - Т. 60. - С. 170-192.

36. Пантусов, Н. Н. Статистические сведения по Кульджинскому району / Н. Н. Пантусов // Материалы для статистики Туркестанского края. -СПб., 1874. - C. 144-205.

37. Первые известия о русских в Кульдже и присоединение к России Киргизской степи / рукопись инока Парфения, сообщенная Д. Ф. Косицыным // Русский вестник. - 1878. - № 9. - С. 6-22.

38. Переписка Военного губернатора Семиреченской области и Туркестанского генерал-губернатора за сентябрь 1871 г. // ЦГА РУз. - Ф. И-1. Оп. 27. - Д. 742. - Л. 7-12 об.

39. Переписка Военного губернатора Семиреченской области Колпаковского и его помощника Россицкого о вырубке лесов в Кульджинском районе 1872-1873 гг. // ЦГА РУз. - Ф. И-1. - Оп. 27. Д. $789 .-$ Л. $1-4$.

40. Письма казачьего офицера с китайской границы // Русский вестник. - 1881. - № 4. - С. 833-852.

41. Поездка С.Н. Алфераки в Кульджинский край. Журнал заседания Совета Императорского 
русского географического общества от 13 февраля 1879 года // ТС. - Т. 348. - С. 146a-148a.

42. Попов, И. М. Россия и Китай: 300 лет на грани войны / И. М. Попов. - М. : Астрель : АСТ : Ермак, 2004. - 547 с. - Электрон. текстовые дан. Режим доступа: https:/history.wikireading.ru/246003 (дата обращения: 27.06.2019). - Загл. с экрана.

43. Потулов, В. В. Колонизационное значение Илийского края / В. В. Потулов. - Петроград : Переселенческое управление, 1917. - 144 с.

44. Почекаев, Р. Ю. Особенности административного развития Илийского края в 1871-1881 гг: между традициями и фронтирной модернизацией / Р. Ю. Почекаев // Общество и государство в Китае. - М. : ИВ РАН, 2016. - Т. XLVI, ч. 2. - С. 531-542.

45. Почекаев, Р. Ю. Особенности правового положении Илийского края в 1760-1860 гг. / Р. Ю. Почекаев // Известия УрФУ. - Серия 2, Гуманитарные науки. - 2018. - Т. 20, № 4 (181). - С. 152-166.

46. Пржевальский, Н. М. От Кульджи за ТяньШань и на Лоб-нор / Н. М. Пржевальский. - М. : ОГИЗ, 1947. - $156 \mathrm{c}$.

47. Путинцев, М. К вопросу о лучшей постановке наших православных миссий / М. Путинцев. М. : Университетская типография, 1891. - Отдельный оттиск № 5 . $-11 \mathrm{c}$.

48. Рапорт Военного министра Туркестанскому генерал-губернатору № 133 от 14.07.1871 г. // ЦГА РУз. - Ф. И-1. - Оп. 27. - Д. 742. - Л. 1-4 об.

49. Распределение контрибуции с населения Илийского округа 05.07.1871 г. // ЦГА РУз. -Ф. И-1. Оп. 27. - Д. 742. - Л. 7-12.

50. Самойлов, Н. А. Россия и Китай / Н. А. Самойлов // Россия и Восток : учеб. пособие / под ред. С. М. Иванова, Б. Н. Мельниченко. - СПб. : Изд-во С.-Петерб. ун-та, 2000. - 456 с.

51. Семенов, А. Покоритель и устроитель Туркестанского края, генерал-адъютант К.П. Фон-Кауфман I : материалы для биогр. сб. / А. Семенов. Электрон. текстовые дан. - Режим доступа: http:// www.vostlit.info/Texts/Dokumenty/M.Asien/XX/ 1900-1920/Kaufmann_sbornik/text1_2.htm (дата обращения: 27.06.2019). - Загл. с экрана.

52. Старцев, А. В. Сибирь и сопредельные территории: история, историография, методология / А. В. Старцев. - Барнаул : БЮИ МВД России, 2016. C. 102-106.

53. Сумароков, А. Кульджа накануне сдачи II / А. Сумароков // ТС. - Т. 331. - С. 245-269.

54. Сунь, Чжинцин. Русская публицистика о проблемах внешней политики России в отношении Китая (конец XIX - начало XX в.) : дис. ... канд. ист. наук / Сунь Чжинцин. - М., 2004. - 246 с.

55. Сутеева, К. А. Русские военные историки XIX века о причинах и мотивах движения России на Восток (в Среднюю Азию и Южный Казахстан)
/ К. А. Сутеева // Центральная Азия и Сибирь. Первые научные чтения памяти Е.М. Залкинда : материалы конф. / под ред. В. А. Моисеева. - Барнаул : Азбука, 2003. - С. 100-116.

56. Темников, Е. Г. Межгосударственные отношения России и Китая во второй половине XIX века : дис. ... канд. ист. наук / Темников Евгений Геннадьевич. - Казань, 2010. - 275 с.

57. Тумайкина, В. В. Основные направления военно-политической и административной деятельности Г.А. Колпаковского : дис. ... канд. ист. наук / Тумайкина Валерия Викторовна. - Барнаул, 2010. - 238 c.

58. Хамзин, И. Р. Кульджинский договор 1851 г. как источник по истории русско-китайских отношений второй половины XIX в.: политические и торгово-экономические аспекты / И. Р. Хамзин // Документ. Архив. История. Современность : материалы VI Междунар. науч.-практ. конф. - Екатеринбург : Уральский университет, 2016. - С. 308-310.

59. Хахалин, К. В. Русско-китайское разграничение в Центральной Азии в середине XVIII - середине XIX в. : дис. ... канд. ист. наук / Хахалин Константин Владимирович. - СПб., 2007. - 183 с.

\section{REFERENCES}

1. Abashin S. Kuldzhinskiy vopros [Kuldjas Question]. Turkestan $v$ imperskoy politike Rossii: monografiya $v$ dokumentakh [Turkestan in Russian Imperial Politics. Monograph in Documents]. Moscow, Kuchkovo pole Publ., 2016, pp. 120-132.

2. Anufriev K.S. Politika Rossii $i$ Kitaya v Tsentralnoy Azii: opyt sravnitelno-istoricheskogo analiza: dis. ... kand. ist. nauk [The Policy of Russia and China in Central Asia: The Experience of Comparative Historical Analysis. Cand. hist. sci. diss.]. Tomsk, 2010. 282 p.

3. Asanova S.A. Otdavat ili ne otdavat Kuldzhu? Obshchestvenno-politicheskiy diskurs 70-80-kh gg. XIX v. [To Give or not to Give Kuldja? Socio-Political Discourse of the $70 \mathrm{~s}-80 \mathrm{~s}$ of the $19^{\text {th }}$ Century]. Tsentralnaya Aziya na perekrestke evropeyskikh $i$ aziatskikh politicheskikh interesov: XVIII-XIX vv.: sb. nauch. tr. Mezhdunar. seminara, g. Alma-Ata, 1923 avgusta $2019 \mathrm{~g}$. [Central Asia at the Crossroads of European and Asian Political Interests: $18^{\text {th }}-$ $19^{\text {th }}$ Centuries. Collection of Scientific Papers of the International Seminar. Alma-Ata, August 19-23, 2019]. Moscow, OntoPrint Publ., 2019, pp. 274-282.

4. Boronin O.V. Problema gosudarstva Yettishar i «Iliyskiy krizis» [The Yettishar State Problem and the Ili Crisis]. Tsentralnaya Aziya v sostave Rossiyskoy imperii [Central Asia as Part of the Russian Empire]. Moscow, Novoe literaturnoe obozrenie Publ., 2008, pp. 78-81. 
5. Bekmakhanova N.E. Prisoedinenie Tsentralnoy Azii k Rossiyskoy imperii v XVIII-XIXvv. Istoriko-geograficheskoe issledovanie [The Accession of Central Asia to the Russian Empire in the $18^{\text {th }}-19^{\text {th }}$ Centuries. Historical and Geographical Research]. Moscow, Saint Petersburg, Institut rossiyskoy istorii RAN, Tsentr gumanitarnykh initsiativ, 2015.240 p.

6. Vasilyev D.V. Bremya imperii. Administrativnaya politika Rossii v Tsentralnoy Azii. Vtoraya polovina XIXv. [The Burden of the Empire. Administrative Policy of Russia in Central Asia. The Second Half of the $19^{\text {th }}$ Century]. Moscow, Politicheskaya entsikopediya, 2018.638 p.

7. Vasilyev D.V. Kitayskiy vopros v Russkom Turkestane: $\mathrm{k}$ istorii rossiyskoy administratsii $\mathrm{v}$ Iliyskom krae [The China Question in Russian Turkestan: On the History of the Russian Administration in the Ili Region]. Vestnik Tomskogo gosudarstvennogo universiteta, 2019, no. 449 (December), pp. 93-101.

8. Vilkins A. Dolina reki Ili [Ili River Valley]. Russkiy vestnik, 1876, no. 8, pp. 483-509.

9. Vozzvanie k kuldzhinskomu naseleniyu [Appeal to the Kuldja Population]. Tsentralnyy gosudarstvennyy arkhiv Respubliki Uzbekistan (dalee$T_{S} G A R U z$ ) [Central State Archive of the Republic of Uzbekistan], f. I-1, inv. 27, d. 742, 1. 5-6 r.

10. Gins G. Taranchi i Dungane: (Ocherki iz poezdki po Semirechyu) [Taranchi and Dungan (Essays from a Trip to Semereche)]. Istoricheskiy vestnik, 1911, no. 8, pp. 673-709.

11. Gorshenina S. Teoriya «estestvennykh granits» i zavoevanie Kuldzhi (1870-1871 gg.): avtoportret rossiyskikh voenno-diplomaticheskikh elit Sankt-Peterburga i Turkestana [The Theory of "Natural Borders" and the Conquest of Kuldja (1870-1871): A Self-Portrait of the Russian MilitaryDiplomatic Elites of St. Petersburg and Turkestan]. $A b$ Imperio, 2014, no. 2, pp. 102-165.

12. Gospodinu voennomu ministru Turkestanskiy general-gubernator $« \mathrm{Ob}$ isproshenii Vysochayshego poveleniya na ostavlenie dokhodov po Kuldzhinskoy provintsii» № 5374 ot 11.12.1871 g. [To the Minister of War by the Governor-General of Turkestan "On requesting the Highest Order to Leave Revenue for Kulja Province" no. 5374 of December 11, 1871]. TsGA $R U z$ [Central State Archive of the Republic of Uzbekistan], f. I-1, inv. 27, d. 743, 1. 1-5.

13. Gurevich V.P. Istoriya «iliyskogo voprosa» $i$ ee kitayskie falsifikatory [The History of the "Ili Question" and Its Chinese Falsifiers]. Dokumenty oprovergayut. Protiv falsifikatsii istorii russkokitayskikh otnosheniy [Documents Refute. Against the Falsification of the History of Russian-Chinese Relations]. Moscow, Mysl Publ., 1982, pp. 423-459.
14. Datsyshen V.G. Istoriya rossiysko-kitayskikh otnosheniy $v$ kontse XIX-nachale XXv. [The History of Russian-Chinese Relations in the Late $19^{\text {th }}-$ Early $20^{\text {th }}$ Centuries]. Moscow, Direkt-Media Publ., 2014. 593 p.

15. Direktor Aziatskogo departamenta Nachalniku glavnogo shtaba, 16 fevralya 1872 goda, № 604 [Director of the Asian Department to the Chief of General Staff, February 16, 1872, no. 604]. TsGA RUz [Central State Archive of the Republic of Uzbekistan], f. I-715, inv. 1, d. 49, 1. 246-248.

16. Direktor MIDa Voennomu ministru, 7 oktyabrya 1870 goda. № 2969 (sekretno) [Director of the Ministry of Foreign Affairs to the Minister of War, October 7, 1870, no. 2969 (classified)]. TsGA $R U z$ [Central State Archive of the Republic of Uzbekistan], f. I-715, inv. 1, d. 44, 1. 225.

17. Direktor MIDa Nachalniku glavnogo shtaba, 9 oktyabrya 1870 goda, № 3006 (doveritelno) [Director of the Ministry of Foreign Affairs to the Chief of the General Staff, October 9, 1870, no. 3006 (confidentially)]. Ts GA RUz [Central State Archive of the Republic of Uzbekistan], f. I-715, inv. 1, d. 44, 1. 233240.

18. Dubrovskaya D.V. Sudba Sintszyana. Obretenie Kitaem «Novoy granitsy» v kontse XIX v. [The Fate of Xinjiang. Chinas Acquisition of the "New Frontier" in the Late 19th Century]. Moscow, Institut vostokovedeniya RAN, 1998. 202 p.

19. Kulikov V.I., ed. «Esli domogatelstva nashi budut udovletvoreny, otdacha Kuldzhi ne budet besplodnoy zhertvoy». Zapiska poslannika Rossii v Kitae E.K. Byutsova. 1878 g. ["If Our Persecution Is Satisfied, Kuldjas Surrender Will not Be a Fruitless Sacrifice". Note by Envoy of Russia to China E.K. Butsov, 1878]. Istoricheskiy arkhiv, 1999, no. 4, pp. 206-212. URL: http://www.vostlit.info/Texts/ Dokumenty/China/XIX/1860-1880/Buezow_E_K/ zapiska_kuldza_1878.htm (accessed 11 May 2019).

20. Zapiska general-mayora Poltoratskogo o znachenii musulmanskogo vosstaniya $\mathrm{v}$ Zapadnom Kitae. 7 marta 1870 g. [Note by Major General Poltoratsky on the Significance of the Muslim Uprising in Western China. March 7, 1870]. TsGA RUz [Central State Archive of the Republic of Uzbekistan], f. I-715, inv. 1, d. 45, 1. 241-260.

21. Zapiska o sovremennom polozhenii nashem na granitse s Zapadnym Kitaem, kapitana Shepeleva. 27 yanvarya 1872 g. [A Note on Our Current Situation on the Border with Western China, Captain Shepelev. January 27, 1872]. TsGARUz [Central StateArchive of the Republic ofUzbekistan], f. I-715, inv. 1, d. 49, 1. 101-123.

22. Kadnikov V.S. Iz istorii Kuldzhinskogo voprosa [From the History of the Kuldja s Issue]. Istoricheskiy vestnik, 1911, no. 124, pp. 893-909.

23. Kopiya s doneseniya Rossiyskogo imperatorskogo Generalnogo konsula v Kuldzhe Vitse- 
direktoru pervogo departamenta Ministerstva inostrannykh del ot 4 fevralya 1910 g. za № 192 [Copy from the Report of the Russian Imperial Consul General in Kuldja to the Vice-Director of the First Department of the Ministry of Foreign Affairs on February 4, 1910 no. 192]. Ts $G A R U z$ [Central State Archive of the Republic of Uzbekistan], f. I-2, inv. 1, d. 261, 1. 21-47 r.

24. Komanduyushchiy voyskami Turkestanskogo okruga Komanduyushchemu voyskami Semirechenskoy oblasti. 23 sentyabrya 1870 g. № 61. Tashkent. Kopiya s kopii (sekretno) [Commander of the Troops of the Turkestan District to the Commander of the Troops of Semirechensk Region. September 23, 1870 no. 61. Tashkent. Copy of the Copy (Classified)]. TsGA RUz [Central State Archive of the Republic of Uzbekistan], f. I-715, inv. 1, d. 44, 1. 132-133.

25. Kulikov V.I. Voennoe ministerstvo i politika Rossii v Kuldzhinskom voprose [The Ministry of War and the Policy of Russia on the Kuldja Issue]. Poltorok S.N., ed. Voyny v Rossii. Sravnitelnyy analiz: materialy 47-y Vseros. zaoch. konf. [The War in Russia. Comparative Analysis. Proceedings of the $47^{\text {th }}$ All-Russian Correspondence Conference]. Saint Petersburg, Nestor Publ., 2007, pp. 49-54.

26. Kuropatkin A.N. Russko-kitayskiy vopros [Russian-Chinese Question]. Saint Petersburg, 1913. $224 \mathrm{p}$.

27. Lendsdel G. Poezdka v Malyy Tibet [Trip to Small Tibet]. Russkoe obozrenie, 1891, no. 12, pp. 700-732.

28. Moiseev V.A. Rossiya i Kitay v Tsentralnoy Azii (vtoraya polovina XIX - 1917 g.) [Russia and China in Central Asia (Second Half of the $19^{\text {th }}$ c. 1917)]. Barnaul, Azbuka Publ., 2003. 346 p.

29. Moiseev S.V. Vzaimootnosheniya Rossii $i$ uygurskogo gosudarstva Yettishar (1864-1877 gg.) [Relations Between Russia and the Uighur State of Yettishar (1864-1877)]. Barnaul, Azbuka Publ., 2006. 200 p.

30. Mushketov I. K voprosu o Kuldzhe [To the Question of Kuldja]. Turkestanskiy sbornik sochineniy i statey, otnosyashchikhsya do Sredney Azii voobshche i Turkestanskomu krayu v osobennosti (dalee - TS) [Turkestan Collection of Essays and Articles Related to Central Asia in General and the Turkestan Region in Particular], vol. 245, pp. 7-14.

31. Bukhert V., ed. «My v nastoyashchee vremya stoim na krayne opasnom puti». Zapiski russkogo diplomata barona F.R. Osten-Sakena ["We Are Currently on an Extremely Dangerous Path". Notes by the Russian Diplomat Baron F.R. Osten-Saken]. Istochnik. Dokumenty russkoy istorii, 2002, no. 1 (55), pp. 13-15.

32. O gornozavodskoy promyshlennosti Kuldzhinskogo khanstva [About the Mining Industry of the Kuldja Khanate]. TS [Turkestan Collection of Essays and Articles Related to Central Asia in General and the Turkestan Region in Particular], vol. 60, pp. 226-231.

33. O Kuldzhe [About Kuldja]. TS [Turkestan Collection of Essays and Articles Related to Central Asia in General and the Turkestan Region in Particular], vol. 60, pp. 202-221.

34. O nastoyashchem polozhenii musulmanskoy insurrektsii v Kitae [On the Current Situation of Muslim Insurrection in China]. TS [Turkestan Collection of Essays and Articles Related to Central Asia in General and the Turkestan Region in Particular], vol. 60, pp. 158-169.

35. Otnosheniya nashi k dunganam, Kashgaru i Kuldzhe [Our Relationship to the Dungans, Kashgar and Kuldja]. TS [Turkestan Collection of Essays and Articles Related to Central Asia in General and the Turkestan Region in Particular], vol. 60, pp. 170-192.

36. Pantusov N.N. Statisticheskie svedeniya po Kuldzhinskomu rayonu [Statistical Reports for Kuldja District]. Materialy dlya statistiki Turkestanskogo kraya [Materials for Statistics of Turkestan Region]. Saint Petersburg, 1874, pp. 144-205.

37. Pervye izvestiya o russkikh v Kuldzhe i prisoedinenie k Rossii Kirgizskoy stepi [The First News of the Russians in Kuldja and the Accession of the Kyrgyz Steppe to Russia]. Russkiy vestnik, 1878, no. 9, pp. 6-22.

38. Perepiska Voennogo gubernatora Semirechenskoy oblasti i Turkestanskogo generalgubernatora za sentyabr $1871 \mathrm{~g}$. [Correspondence of the Military Governor of Semirechensk Region and the Turkestan Governor General for September 1871]. $T_{s} G A R U z$ [Central State Archive of the Republic of Uzbekistan], f. I-1, inv. 27, d. 742, 1. 7-12 r.

39. Perepiska Voennogo gubernatora Semirechenskoy oblasti Kolpakovskogo i ego pomoshchnika Rossitskogo o vyrubke lesov v Kuldzhinskom rayone 1872-1873 gg. [Correspondence of the Military Governor of Semirechensky Region Kolpakovsky and His Assistant Rositsky on Deforestation in Kuldja District of 1872-1873]. TsGA $R U z$ [Central State Archive of the Republic of Uzbekistan], f. I-1, inv. 27, d. 789, 1. 1-4.

40. Pisma kazachyego ofitsera s kitayskoy granitsy [Letters of a Cossack Officer from the Chinese Border]. Russkiy vestnik, 1881, no. 4, pp. 833-852.

41. Poezdka S.N. Alferaki v Kuldzhinskiy kray. Zhurnal zasedaniya Soveta Imperatorskogo russkogo geograficheskogo obshchestva ot 13 fevralya 1879 goda [Trip S.N. Alferaki in the Kuldja Region. Journal of the Meeting of the Imperial Russian Geographical Society Council of February 13, 1879]. TS [Turkestan Collection of Essays and Articles Related to Central Asia in General and the Turkestan Region in Particular], vol. 348, pp. 146a-148a.

42. Popov I.M. Rossiya i Kitay: 300 let na grani voyny [Russia and China: 300 Years on the Brink of 
War]. Moscow, Astrel Publ., AST Publ., Ermak Publ., 2004. 547 p. URL: https://history.wikireading.ru/246003 (accessed 27 July 2019).

43. Potulov V.V. Kolonizatsionnoe znachenie Iliyskogo kraya [Colonization Value of the Ili Region]. Petrograd, Pereselencheskoe upravlenie Publ., 1917. 144 p.

44. Pochekaev R.Yu. Osobennosti administrativnogo razvitiya Iliyskogo kraya v 1871-1881 gg.: mezhdu traditsiyami i frontirnoy modernizatsiey [Features of the Administrative Development of the Ili Region in 1871-1881: Between Traditions and Frontier Modernization]. Obshchestvo i gosudarstvo v Kitae [Society and State in China]. Moscow, IV RAN, 2016, vol. XLVI, part 2, pp. 531-542.

45. Pochekaev R.Yu. Osobennosti pravovogo polozhenii Iliyskogo kraya v 1760-1860 gg. [Features of the Legal Status of the Ili Region in 1760-1860]. Izvestiya UrFU. Seriya 2. Gumanitarnye nauki, 2018, vol. 20, no. 4 (181), pp. 152-166.

46. Przhevalskiy N.M. Ot Kuldzhi za Tyan-Shan i na Lob-nor [From Kuldja Beyond the Tien Shan and to Lob-Nor]. Moscow, OGIZ Publ., 1947. 156 p.

47. Putintsev M. K voprosu o luchshey postanovke nashikh pravoslavnykh missiy [The Question of the Best Formulation of Our Orthodox Missions]. Moscow, Universitetskaya tipografiya, 1891, offprint no. 5. 11 p.

48. Raport Voennogo ministra Turkestanskomu general-gubernatoru № 133 ot $14.07 .1871 \mathrm{~g}$. [Report of the Minister of War to the Turkestan Governor General of July 14, 1871 no. 133]. Ts GA RUz [Central State Archive of the Republic of Uzbekistan], f. I-1, inv. 27, d. 742,1.1-4 r.

49. Raspredelenie kontributsii s naseleniya Iliyskogo okruga 05.07.1871 g. [Distribution of Resources with the Population of the Ili District. July 5, 1871]. TsGA RUz [Central State Archive of the Republic of Uzbekistan], f. I-1, inv. 27, d. 742, 1. 7-12.

50. Samoylov N.A. Rossiya i Kitay [Russia and China]. Rossiya i Vostok: ucheb. posobie [Russia and the East: Textbook]. Saint Petersburg, Izd-vo SanktPeterburgskogo universiteta, 2000. $456 \mathrm{p}$.

51. Semenov A. Pokoritel $i$ ustroitel Turkestanskogo kraya, general-adyutant K.P. FonKaufman I: materialy dlya biogr. sb. [Conqueror and Organizer of the Turkestan Territory, Adjutant General K.P. Fon-Kaufman I. Materials for Biographic Collection]. URL: http://www.vostlit.info/Texts/ Dokumenty/M.Asien/XX/1900-1920/Kaufmann sbornik/text1_2.htm (accessed 27 July 2019).

52. Startsev A.V. Sibir $i$ sopredelnye territorii: istoriya, istoriografiya, metodologiya [Siberia and Adjacent Territories: History, Historiography,
Methodology]. Barnaul, BYuI MVD Rossii Publ., 2016, pp. 102-106.

53. Sumarokov A. Kuldzha nakanune sdachi II [Kuldja on the Eve of Surrender II]. TS [Turkestan Collection of Essays and Articles Related to Central Asia in General and the Turkestan Region in Particular], vol. 331, pp. 245-269.

54. Sun Chzhintsin. Russkaya publitsistika o problemakh vneshney politiki Rossii $v$ otnoshenii Kitaya (konets XIX - nachalo XX v.): dis. ... kand. ist. nauk [Russian Journalism About the Problems of Russias Foreign Policy Towards China (Late $19^{\text {th }}-$ Early $20^{\text {th }}$ Centuries). Cand. hist. sci. diss.]. Moscow, 2004. 246 p.

55. Suteeva K.A. Russkie voennye istoriki XIX veka o prichinakh i motivakh dvizheniya Rossii na Vostok (v Srednyuyu Aziyu i Yuzhnyy Kazakhstan) [Russian Military Historians of the $19^{\text {th }}$ Century on the Causes and Reasons for the Movement of Russia to the East (To Central Asia and South Kazakhstan)]. Tsentralnaya Aziya i Sibir. Pervye nauchnye chteniya pamyati E.M. Zalkinda: materialy konf. [Central Asia and Siberia. The First Scientific Readings in Memory of E.M. Zalkind. Proceedings of the Conference]. Barnaul, Azbuka Publ., 2003, pp. 100-116.

56. Temnikov E.G. Mezhgosudarstvennye otnosheniya Rossii i Kitaya vo vtoroy polovine XIX veka: dis. ... kand. ist. nauk [Interstate Relations Between Russia and China in the Second Half of the $19^{\text {th }}$ Century. Cand. hist. sci. diss.]. Kazan, 2010. 275 p.

57. Tumaykina V.V. Osnovnye napravleniya voenno-politicheskoy $i$ administrativnoy deyatelnost $i$ G.A. Kolpakovskogo: dis. ... kand. ist. nauk [The Main Areas of Military-Political and Administrative Activity of G.A. Kolpakovsky. Cand. hist. sci. diss.]. Barnaul, 2010. 238 p.

58. Khamzin I.R. Kuldzhinskiy dogovor $1851 \mathrm{~g}$. kak istochnik po istorii russko-kitayskikh otnosheniy vtoroy poloviny XIX v.: politicheskie i torgovoekonomicheskie aspekty [The Kuldja Treaty of 1851 as a Source on the History of Russian-Chinese Relations of the Second Half of the $19^{\text {th }}$ Century: Political, Trade and Economic Aspects]. Dokument. Arkhiv. Istoriya. Sovremennost: materialy VI Mezhdunar. nauch.-prakt. konf. [Document. Archive. History. Present. Materials of the VI International Scientific and Practical Conference]. Yekaterinburg, Uralskiy universitet, 2016, pp. 308-310.

59. Khakhalin K.V. Russko-kitayskoe razgranichenie $v$ Tsentralnoy Azii v seredine XVIIIseredine XIX v.: dis. ... kand. ist. nauk [The RussianChinese Demarcation in Central Asia in the Mid- $18^{\text {th }}$ Mid-19 $9^{\text {th }}$ Centuries. Cand. hist. sci. diss.]. Saint Petersburg, 2007. 183 p. 


\section{ИСТОРИЯ ЦЕНТРАЛЬНО-АЗИАТСКОГО РЕГИОНА}

\section{Information About the Author}

Svetlana A. Asanova, Candidate of Sciences (History), Acting Associate Professor, Department of Social, Humanitarian Disciplines, National Research Technological University "MISiS" Almalyk Branch, Amira Temura St, 56, 110100Almalyk, Republic ofUzbekistan, asa_svetlana@mail.ru, https://orcid.org/0000-0003-0311-2254

\section{Информация об авторе}

Светлана Алексеевна Асанова, кандидат исторических наук, и.о. доцента кафедры социально-гуманитарных дисциплин, Алмалыкский филиал Национального исследовательского технологического университета «МИСиС», ул. Амира Темура, 56, 110100 г. Алмалык, Республика Узбекистан, asa_svetlana@mail.ru, https://orcid.org/0000-0003-0311-2254 